\title{
Applications of Geographic Information Systems (GIS) to habitat assessment and marine resource
}

\section{management}

\author{
Katherine B. STANBURY*, Richard M. STARR \\ University of California Sea Grant Extension Program, PO Box 440, Moss Landing, CA 95039, USA
}

Revised 28 May 1999; accepted 10 June 1999

\begin{abstract}
Marine scientists often assess habitats to understand the distribution and relative abundance of marine resources. Due to the spatial nature of habitats and associated temporal changes, however, assimilating data using traditional analytical methods is often difficult. Geographic Information Systems (GIS) are proving to be effective tools to help address problems inherent in the analysis of spatial data. GIS can be used to effectively collate, archive, display, analyze, and model spatial and temporal data. Additionally, by combining dissimilar data types, such as socio-political boundaries, bottom types, and fish distributions, for example, resource managers can use GIS to make informed management decisions. In this way, GIS provides resource managers with a means to integrate scientific data with prevailing cultural values and traditions. We have developed a working GIS for the Monterey Bay National Marine Sanctuary that allows interpretation of many terrestrial and marine data sets, including inter-tidal monitoring data, permit locations, seabird strandings, fisheries catch data, habitat types, marine political boundaries, as well as land cover classification from satellite imagery, watersheds, streams, roads, and political boundaries. We have linked terrestrial and marine data to create a broad spatial and temporal database that will be used in a variety of ways such as evaluating natural processes, permitting and monitoring coastal development and assessing environmental impacts (e.g. oil spills). (C) 1999 Ifremer / CNRS / IRD / Éditions scientifiques et médicales Elsevier SAS
\end{abstract}

geographic information system / marine sanctuary / resource management

Résumé -- Utilisation des systèmes d'information géographique (SIG) pour déterminer l'habitat et gérer les ressources marines. Les scientifiques déterminent souvent les habitats pour comprendre la répartition et l'abondance relative des ressources marines. Pourtant, en raison de la variabilité spatiale et temporelle des données, leur assimilation par les méthodes d'analyse traditionnelles est souvent difficile. Les systèmes d'information géographique (SIG) se révèlent efficaces pour traiter ces problèmes. Ils permettent de collecter, classer, visualiser, analyser et modéliser les données spatiales et temporelles. En combinant des données de natures différentes telles que limites socio-politiques, types d'habitats et répartition des espèces de poissons, les gestionnaires des ressources peuvent prendre leurs décisions en connaissance de cause. Ainsi, le SIG constitue un moyen d'intégrer les données scientifiques aux valeurs et traditions culturelles de l'époque. Les auteurs ont développé un SIG pour la réserve marine nationale de la baie de Monterey. Il permet d'interpréter des jeux de données terrestres et marines comprenant, entre autres, les marées, les zones de décharges autorisées, les sites d'échouage des oiseaux de mer, les captures de pêches, les types d'habitats, les limites politiques marines ; il permet aussi la classification de la couverture terrestre par imagerie satellitale, bassins hydrographiques, fleuves, routes et limites politiques. Les données terrestres et marines sont réunies dans une grande base de données spatiales et temporelles offrant un choix important d'applications pour l'évaluation des processus naturels, l'autorisation et la surveillance du dévelopement côtier et l"évaluation de lcurs impacts sur l'environnement (par exemple, les marées noires). (O 1999 lfremer / CNRS / IRD / Éditions scientifiques et médicales Elsevier SAS

\section{systèmes d'information géographique / réserve marine / gestion des ressources}

$\overline{* \text { Correspondence and reprints: stanbury } @ \mathrm{~m} / \mathrm{ml} . c a l s t a t e . e d u}$ 


\section{INTRODUCTION}

Increasing coastal development requires that management decisions be made regardless of whether or not comprehensive scientific studies are available to be incorporated into the decision making process. Often helpful scientific information is overlooked or ignored because of the difficulty in combining dissimilar data types. This is especially true in coastal resource management because of the spatially and temporally dynamic nature of marine habitats. GIS is a tool that can be used to combine scientific and cultural data to assess and manage marine habitats. In order to help resource managers improve policy decisions, we have developed a prototype GIS for the Monterey Bay National Marine Sanctuary (MBNMS) using preexisting spatial data. Using the Sanctuary as a case study, we will describe the components of the project, providing a framework for any potential GIS application with marine resource management objectives.

GIS is an "organized collection of computer hardware, software, geographic data, and personnel designed to efficiently capture, store, update, manipulate, analyze, and display all forms of geographically referenced information" [1]. Objects of the same type, such as political boundaries, are grouped into a layer, also referred to as themes or coverages. Geographically referenced coverages are linked to data contained in attribute tables. The power of GIS lies in the ability to combine or overlay themes, conduct spatial analysis and perform queries within one layer or among objects in two or more layers. For example, assume a manager had the offshore bathymetric contours stored in one layer and positions of fishing locations in another layer. A within-layer query might derive the area circumscribed by the $50-\mathrm{m}$ depth contour or the distance between ports and consecutive fishing locations. By combining layers, more complex questions can be addressed. The manager might now ask for all fishing locations in water depths greater than $50 \mathrm{~m}$. Adding additional layers, such as a layer describing habitat types as determined by sidescan sonar, the queries that can be performed grow exponentially. GIS is not the only means of answering these questions, but it allows for increased speed and accuracy, thus allowing decision makers to evaluate various proposed management scenarios and make more informed decisions.

National Marine Sancluaries in the United States are an example of marine protected areas that are actively managed. As the largest of 14 national marine sanctuarics in the U.S., the Monterey Bay National Marine Sanctuary spans over $13726 \mathrm{~km}^{2}$ along $580 \mathrm{~km}$ of central California, extending from the mean high tide line to approximately $55 \mathrm{~km}$ offshore. The primary activities of the Sanctuary program are the coordination of research, monitoring, education, and permitting activities.

\section{MATERIALS AND METHODS}

To maximize the effectiveness of GIS, it is important to clearly articulate the tool's use-objectives. As such, our first task was to identify data needs for managing the coastal and marine resources encompassed within the boundaries of the Sanctuary. Through discussion with Sanctuary staff, we identified and focused on collecting information relevant to six primary management issues pertinent to the Sanctuary; 1) coastal development and erosion, 2) water quality assessment and monitoring, 3) oil spills: prevention and emergency contingency planning, 4) protection of local endangered or threatened species, 5) habitat monitoring and assessment, and 6) fisheries depletion. Bearing these management objectives in mind, the next task was to survey various agencies to identify available electronic data sets. Our project attempts to overcome the difficulties inherent to managing a large and diverse ecosystem by combining previously disparate GIS data layers, such as satellite images, aerial photographs, existing maps, and database information from multiple sources. By combining the information resources of a number of agencies in the region into a single geographically rectified source, the ability of the Sanctuary staff to develop ecosystem based management solutions is greatly enhanced.

An important component of an organized and meaningful database is the collection of metadata. Metadata is essentially documentation of all the parameters defining a dataset. Collecting metadata reduces information loss during data exchange among dissimilar computer platforms. Collecting metadata is a sometimes daunting but always crucial task. Available electronic data sets are often second or third generation, or even sometimes of untraceable origin. Following metadata standards and documenting the history of database changes made increases the quality and integrity of spatial data quality as well as facilitating data exchange among agencies and institutions. Using California Geographic Information Association metadata standards as a template, each metadata filc included the following fields: Title, Abstract, Database Status, Maintenance and Update Frequency, 
Table I. Description of the fields in CGIA Geospatial Database Catalogue

\begin{tabular}{|c|c|}
\hline FIELD & DESCRIPTION \\
\hline Title & Enter a common name for the data set. \\
\hline Description/Abstract & Include at brief description of the data set and its primary intended purpose. \\
\hline Database Contact & $\begin{array}{l}\text { Indicate whether the database is 'complete' and being used today by your organization. } \\
\text { If it is in a developmental stage, select 'In work'. }\end{array}$ \\
\hline Maintenance and Update Frequency & Indicate the frequency of maintenance which occurs on the data set. \\
\hline Theme Keywords & Select keyword codes as alternate catalog search keys. \\
\hline Place Keywords & In a few words, name the geographic extent of thespatial data set. \\
\hline Use Constraints & Indicate restrictions and legal prerequisites for using the data set after access is granted. \\
\hline$\Lambda$ ccess Constraints & Indicate restrictions and legal prerequisites for accessing the data set. \\
\hline Native Data Set Environment & Select the name of the dataset format used for file transfer. For example, DLG (digital line graph). \\
\hline Database Contact Information & Contact information for an individual or organization that is knowledgeable about the data set. \\
\hline Additional Information & Provide written instructions on how to contact your organization regarding this specific data set. \\
\hline Source Scale Denominator & $\begin{array}{l}\text { The denominator of the representative fraction on the source map (for example, on a 1:24 } 000 \text { scale } \\
\text { map, the Source Scale Denominator is } 24000 \text { ). }\end{array}$ \\
\hline Lineage Source Information & $\begin{array}{l}\text { Provide a brief discussion of the source information used, method of automation, date of information } \\
\text { collection, and indicate the reference basemap to which the data set aligns. }\end{array}$ \\
\hline Coordinate System & Select the coordinate system used to define the data set. \\
\hline Entity Type & Select all appropriate types of entities represented in the data set. \\
\hline Transter Size & The size of the transferred data set in megabytes \\
\hline
\end{tabular}

Theme Keywords, Place Keywords, Use Constraints, Access Constraints, Native Data Set Environment, Database Contact Information, Additional Information, Source Scale Denominator, Coordinate Systems, Entity Type, Transfer Size, and a list of all associaled files (table I).

Once collected, many data sets had to be manipulated in GIS software to ensure compatibility regarding projection and distance units. After standardization, it was important to combine the layers in a meaningful way that addressed the management needs of the Sanctuary (table $I I$ ).

\section{RESULTS}

Many coastal areas are undergoing dramatic changes, feeling the impact of human activities dealing with economic, land use, and resource development. We incorporated a series of aerial photographs and digital orthographic quadrangles in the GIS for managers to use to analyze land-use patterns. Aerial photographs are relatively inexpensive and cspccially useful for change detection due to their high resolution and multi-temporal coverage. These images can be used to identify and map wetlands as well as seasonal and long-term changes in water quality.

In the Monterey Bay region, a good deal of information is needed to improve the management of non-point source pollution. Agricultural runoff is significant in the area
Table II. Electronic Data Sets Acquired and Associated Agencies

\begin{tabular}{ll}
\hline ACQUIRED SPATIAL DATA & AGENCY \\
\hline Public Lands Survey Data & CA Coastal Commission \\
National Wetlands Inventory Map & CA Coastal Commission \\
DLG Stream Data & CA Coastal Commission \\
Watersheds & CA Coastal Commission \\
CA Coastline & CA Dept. Fish \& Game \\
Sanctuary Boundaries & OSPR \\
NPDES Pcrmit Data & MBNMS \\
Bathymetry & MBARI \\
Environmental Sensitivity Index & NOAA, HAZMAT \\
Geology \& Fault Lines & MBARI \\
Aerial Photos & CA Coastal Commission \\
Digital Orthographic Quadrangle & CA Coastal Commission \\
Photos & \\
\hline
\end{tabular}

and the Sanctuary takes an active role to reduce sediment and pesticide delivery to watersheds and consequently the bay. One useful layer collected is a land cover classification derived from a LANDSAT satellite image. This layer was combined with watershed boundaries and stream courses. Using information such as this, models can be developed to identify watersheds at risk due to high rates of erosion and sedimentation. After at-risk watersheds have been targeted, managers can better allocate funding resources needed to conduct water quality monitoring. We have also used GIS to map point source dischargc sites. As a permitting and enforcement agency it is important for the Sanctuary to have access to discharge site locations and relevant attribute information. 
Due to heavy ship traffic along the coast, the threat of oil spills is a major concern of the Sanctuary. An Environmental Sensitivity Index (ESI) was developed by the Hazardous Material division of NOAA. The ESI provides a useful first step in the design of contingency plans because it enables managers to identify priority areas for protection from oiling and determination of appropriate shoreline clean-up methods during response activities. The ESI ranks shoreline environments as to their relative sensitivity to oil spills, potential biological injury, and ease of clean-up. The combination of geomorphology, the degree of exposure to waves and currents, and the plants and animals that inhabit the shoreline are the main criteria that determine sensitivity rankings. During a spill and for planning purposes, the GIS can provide maps of loca tions of sensitive areas as well as information associated with these sensitive areas. Sensitive areas may include wildlife management area boundaries, national and state park boundaries, fishing and spawning areas for fish and crustaceans, water intakes, sea. grass beds, and seabird nesting sites. Multiple databases are associated with the ESI which allow the user access to complex biological data as well as information about human-use resources (table III).

Despite its applicability, GIS technology remains underutilized in fisheries sciences [3]. Fishery logbook and research trawl data provide a detailed set of catch and

Table III. Examples of Fields included in ESI Data Sets.

\section{ATTRIBUTE DESCRIPTION \& FIELDS}

TABLE

SPECIES The species table contains the common name (NAMF), the scientific name (GEN_SPEC), the state and federal status (S_F), and the threatened or endangered status (T_E). The items SUBELEMENT or ABBR refer to the grouping of species and the associated abbreviation.

SEASONAL The seasonal table stores the monthly presence of each species and the characteristics of the presence (life history information) and includes fields such as element, species, ID, season ID,

BIORES The bioresources table contains the species ID, concentration, season ID, expert ID, and element

EXPERTS The experts table contains a list of experts who may be contacted during an oil spill. BIORES and EXPERTS are linked using the field EXPERT_ID

SOC_DATA SOC_DATA pertains to human-use or socioeconomic features and includes fields such as feature type, contact person, the owner of the facility, phone number and any commonts regarding the site. effort data with broad temporal and spatial coverage ideally suited to a GIS. Using GIS, Fox and Starr [2] mapped fishery and research catch locations for five species and compared catch distribution patterns, catch rates, and biomass estimates. It is our intention to create and include a similar database for Sanctuary use thus providing useful estimates of the distribution and abundance of commercial fish species.

\section{DISCUSSION}

The process and precision of acquiring spatial data has been greatly enhanced by technologies such as remote sensing and global positioning systems. As personal computers become increasing powerful and available, GIS has become an attractive tool for facilitating ecosystem-based management decisions. However, the increased use of GIS involves various important considerations. How suitable is it to combine various data collected for very different objectives? There are issues of scale and spatial statistics. How accurate is the information derived from basic modeling? Information resulting from database queries will have error associated with it how is this error to be evaluated and how accurate are the conclusions drawn from such a query? One approach to ensure data quality is persistent and meticulous metadata collection. Standardization of spatial data and associaled metadata will greatly reduce error. This project was facilitated by a decision on the part of many local agencies to participate in a joint data sharing agreement. Ownership of data must be considered but generating new spatial data is time consuming and sometimes training intensive. It is inefficient to replicate data that already exists, so an environment of data sharing is crucial to efficient production and subsequent availability to various agencies.

\section{CONCLUSION}

GIS provides a natural framework for the acquisition and analysis of geo-referenced biological, oceanographic, environmental, and cultural data. The database we have compiled for the MBNMS serves as powerful basemap for management purposes. This dataset can ultimately be used to answer questions regarding habitat feature locations, temporal changes, spatial patterns, and system modeling. The next phase of our project is to incorporate data from an intertidal monitoring program as well as long-term seabird stranding data. These data sets can be 
used to evaluate long-term trends in species composition and relative densities, serving as indicators of overall long-term ecosystem viability as well as the effects of natural phenomena.

\section{Acknowledgements}

We would like to thank Andrew DeVogelaere of the Monterey Bay National Marine Sanctuary for comment- ing on drafts of the manuscript and Ray McClain of Moss Landing Marine Laboratories for technical advice and support throughout this project. The Monterey Bay National Marine Sanctuary and California Urban Environmental Research and Education Center provided funding for this project. The Center for Habitat Studies is jointly supported by Moss Landing Marine Laboratories, California State University, Monterey Bay, and the University of California Sea Grant Extension Program.

\section{REFERENCES}

[1] Enyironmental Systems Research Institute (ESRI), Understanding GIS, the ARC/INFO method, Environmental Systems Research Institute, Inc., Redlands, CA, 1990, 423 p.

[2] Fox D.S., Starr R.M., Comparison of commercial fishery research and catch data, Can. J. Fish. Aquat. Sci. 53 (1996) $2681-2694$.
[3] Isaak D.J., Hubert W.A., Integrating new technologies into fisheries science: the application of geographic information systems, Fisheries 22 (1997) 6-10. 